\title{
Renal neuraminidase
}

\section{Characterization in normal rat kidney and measurement in experimentally induced nephrotic syndrome}

\author{
William H. BARICOS, ${ }^{*} \ddagger$ Shirley CORTEZ-SCHWARTZ* and Sudhir V. SHAH $\dagger$ \\ Departments of *Biochemistry and †Medicine, Tulane Medical School, 1430 Tulane Avenue, New Orleans, LA 70112, U.S.A.
}

\begin{abstract}
Several lines of evidence suggest that increased neuraminidase activity may be responsible for the loss of glomerular $\mathrm{N}$-acetylneuraminic acid (AcNeu) observed in various glomerular diseases. However, virtually no information is available on the activity of neuraminidase in glomeruli or the potential role of this enzyme in glomerular pathophysiology. Utilizing $2^{\prime}$-(4-methylumbelliferyl)- $\alpha$-D- $N$-acetylneuraminic acid (4MU-AcNeu) as substrate, we defined optimal assay conditions and characterized neuraminidase activity in glomeruli and, for comparison, in other renal fractions and liver. Neuraminidase activity in glomeruli, cortex and tubules was maximal at pH 4.4. The $K_{\mathrm{m}}$ for $4 \mathrm{MU}-\mathrm{AcNeu}$ was estimated to be $195 \mu \mathrm{M}$ for glomeruli and $226 \mu \mathrm{M}$ for cortex. Glomerular neuraminidase was inhibited by AcNeu $(90 \%$ at $25 \mathrm{~mm})$ and high concentrations of Triton X-100 $(26 \%$ at $0.5 \%)$, but unaffected by $\mathrm{CaCl}_{2}$, EDTA or $N$-ethylmaleimide (each $1 \mathrm{~mm}$ ). Neuraminidase activity (nmol/h per mg of protein; mean \pm S.E.M.) in normal rat kidney was: cortex, 14.47 \pm 0.76 ; medulla, $7.85 \pm 0.64$; papilla, $2.64 \pm 0.11$; tubules, $13.79 \pm 0.70$; glomeruli, $5.57 \pm 0.28$. In comparison, neuraminidase activity in rat liver was $2.58 \pm 0.14$. Puromycin aminonucleoside (PAN)induced nephrotic syndrome is a model of glomerular disease in which the loss of glomerular AcNeu is well documented. In two separate studies, we observed no change in the specific activity of neuraminidase in either glomeruli or cortex isolated from rats treated with PAN $(15 \mathrm{mg} / 100 \mathrm{~g}$, intraperitoneally) and killed at either the onset or the peak of proteinuria. Results were similar whether neuraminidase activity was expressed per mg of protein or per $\mu \mathrm{g}$ of DNA.
\end{abstract}

\section{INTRODUCTION}

The glomerulus is a specialized capillary tuft located in the renal cortex, which carries out ultrafiltration of the plasma. The epithelial cells of the glomerulus are normally coated with a negatively charged glycoprotein referred to as the epithelial polyanion or glomerular polyanion (GPA). The GPA is postulated to play important roles in several aspects of glomerular pathophysiology (Michael et al., 1970; Blau \& Haas, 1973; Couser et al., 1978; Kanwar \& Farquhar, 1980). A key role for $\alpha$-D- $N$-acetylneuraminic acid (AcNeu, sialic acid) as the negatively charged component of the GPA was suggested by early experiments (Mohos \& Skoza, 1969; Michael et al., 1970; Andrews, 1979) which demonstrated the loss of negative charge from GPA after treatment with neuraminidase (EC 3.2.1.18), an enzyme which cleaves AcNeu from sialoglycoproteins and sialoglycolipids (Suzuki, 1976). These early suggestions were subsequently confirmed by Farquhar and coworkers, who isolated and characterized the GPA as a $140000-M_{\mathrm{r}}$ sialoglycoprotein containing approx. $4.5 \%$ AcNeu (Kerjaschki et al., 1984).

Loss of glomerular AcNeu is a corsistent finding in a variety of human and experimental glomerular diseases (Michael et al., 1970; Chiu \& Drummond, 1972; Blau \& Haas, 1973; Bertani et al., 1982; Kerjaschki et al., 1985). Several lines of evidence suggest that increased activity of glomerular neuraminidase may be responsible for this loss. These include: the well-documented ability of neuraminidase to cleave AcNeu from the GPA (Mohos \& Skoza, 1969; Michael et al., 1970; Andrews, 1979); the finding of normal or increased biosynthesis of GPA in the puromycin aminonucleoside (PAN) model of glomerular nephritis (Blau \& Michael, 1972); and increased activity of renal neuraminidase in diabetic nephropathy, a condition also characterized by decreased glomerular AcNeu (Cohen-Forterre et al., 1984).

Neuraminidase activity has been measured and characterized in a variety of tissues (Rosenberg \& Schengrund, 1976), including kidney (Carubelli et al., 1962; Mahadevan et al., 1967; Kuratowska \& Kubicka, 1967; Tuppy \& Palese, 1968; Kirschbaum \& Bosmann, 1973; Mutton et al., 1978; Cohen-Forterre et al., 1984). The enzyme is predominantly lysosomal, although in some tissues a non-lysosomal form(s) has also been reported (Kuratowska \& Kubicka, 1967; Horvat \& Touster, 1968; Tulsiani \& Carubelli, 1970, 1971; Meyer et al., 1981). However, in rat kidney, only the lysosomal form has been demonstrated (Cohen-Forterre et al., 1984). Virtually no information is available on the activity of neuraminidase in glomeruli or the potential role of this enzyme in glomerular disease.

In the present study we have utilized 2'-(4-methylumbilliferyl)- $\alpha$-D- $N$-acetylneuraminic acid (4MU$\mathrm{AcNeu}$, a sensitive and specific fluorogenic substrate, for the measurement and biochemical characterization of

\footnotetext{
Abbreviations used: PAN, puromycin aminonucleoside [6-dimethylamino-9-(3'-amino-3'-deoxyribosyl)purine]; 4MU-AcNeu, 2'-(4-methylumbelliferyl)- $\alpha$-D- $N$-acetylneuraminic acid; AcNeu, $\alpha$-D- $N$-acetylneuraminic acid; GPA, glomerular polyanion; HBSS, Hanks balanced salt solution.

$\ddagger$ To whom correspondence should be addressed.
} 
neuraminidase in glomeruli and, for comparison, other renal fractions. In addition we have measured the specific activity of neuraminidase in glomeruli obtained from rats with PAN-induced nephrotic syndrome (Frenk et al., 1955), a model of glomerular disease in which the loss of glomerular AcNeu is well documented (Michael et al., 1970; Kerjaschki et al., 1985; Charest \& Roth, 1985).

\section{EXPERIMENTAL}

\section{Materials}

Male Sprague-Dawley rats $(250-300 \mathrm{~g})$ were obtained from Charles River Breeding Laboratories, Wilmington, MA, U.S.A. PAN, 4-methylumbelliferone, 4MU-AcNeu, 4-nitrophenyl $\alpha$-L-fucoside and Triton X-100 were obtained from Sigma Chemical Co., St. Louis, MO, U.S.A. Nitex sieves were purchased from Tetko, Elmsford, NY, U.S.A. Other chemicals were reagent grade or higher.

\section{Preparation of tissue homogenates}

Rats were anaesthetized with pentobarbital $(50 \mathrm{mg} / \mathrm{kg}$ ). A polyethylene catheter (PE 100) was inserted into the lower abdominal aorta immediately above the bifurcation, and $2-3 \mathrm{ml}$ of blood was drawn into a heparinized syringe. Subsequently the aorta was clamped above the renal arteries, the renal veins were cut, and the kidneys perfused with ice-cold $\left(0-4^{\circ} \mathrm{C}\right)$ Hanks Balanced Salt Solution (HBSS). After blanching, the kidneys were rapidly removed and decapsulated, and cortex, medulla and papilla were carefully separated by dissection. All subsequent steps were carried out at 0 $4{ }^{\circ} \mathrm{C}$. Homogenates $(10 \%, \mathrm{w} / \mathrm{v})$ of cortex, medulla, papilla and liver were prepared in $0.15 \mathrm{M}$-potassium

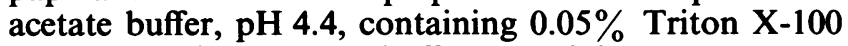
(hereafter referred to as 'buffer'). Each homogenate was sonicated for $5 \mathrm{~s}$ at $0-4^{\circ} \mathrm{C}$ (Heat Systems-Ultrasonics Cell Disrupter, model W-375; ultra-micro tip; power setting 5).

\section{Isolation of glomeruli and tubules}

Glomeruli and tubules were isolated by a combination of differential centrifugation and sieving as described in our previous study (Baricos \& Shah, 1984). In the studies of PAN-induced nephrotic syndrome, after perfusion a small piece of cortex from each animal was immediately fixed in $10 \%$ neutral buffered formalin for colloidal-iron staining of glomerular AcNeu. All subsequent steps were carried out at $0-4^{\circ} \mathrm{C}$. The remaining cortex was minced and gently pressed through a stainless-steel sieve $(250 \mu \mathrm{m}$ opening). The resulting suspension was washed several times in HBSS by repeated centrifugation $(200 \mathrm{~g}, 2 \mathrm{~min})$ to eliminate small fragments. The pellet was resuspended in HBSS and sequentially passed through Nitex nylon sieves of $390 \mu \mathrm{m}, 250 \mu \mathrm{m}$ and $180 \mu \mathrm{m}$ pore sizes. The particles retained on the $390 \mu \mathrm{m}$ and $250 \mu \mathrm{m}$ sieves, consisting primarily of fragments of the proximal tubules, were pooled to give the tubular fraction. This tubular fraction was washed again on the $250 \mu \mathrm{m}$ nylon sieve with HBSS to render glomerular contamination negligible. The washed tubules were collected by centrifugation $(200 \mathrm{~g}, 2 \mathrm{~min})$ and resuspended in $6.0 \mathrm{ml}$ of buffer. After gentle but thorough mixing, $2.0 \mathrm{ml}$ of this preparation was sonicated as described above.

The suspension passing through the $180 \mu \mathrm{m}$ sieve was passed over a Nitex no. 25 screen cloth (pore opening about $60 \mu \mathrm{m}$ ), which retains glomeruli. Glomeruli prepared in this way are well preserved and without capsules. The purity of each preparation of glomeruli was evaluated by light-microscopy. All preparations used in the present study were more than $90 \%$ pure. After the determination of purity, glomeruli were collected by centrifugation $(200 \mathrm{~g}, 2 \mathrm{~min})$, resuspended in $0.5 \mathrm{ml}$ of buffer, and sonicated as described above.

After removal of samples for neuraminidase and protein determination, the remainder of each preparation was divided into small batches, frozen in liquid $\mathrm{N}_{2}$ and stored at $-80^{\circ} \mathrm{C}$.

\section{Induction of experimental nephrotic syndrome}

Male Sprague-Dawley rats were housed in individual metabolic cages with free access to standard rat chow and water for at least 2 days before injection. Urine was collected every $24 \mathrm{~h}$, usually between 08:00 and 09:00 h. As described in our previous study (Baricos \& Shah, 1984) and by others (Velosa et al., 1981; Abboud et al., 1982), PAN-induced nephrotic syndrome was induced in rats by a single intraperitoneal injection of PAN $(15 \mathrm{mg} / 100 \mathrm{~g}$ body wt. $)$ in sterile saline $(0.9 \% \mathrm{NaCl})$. In this model proteinuria consistently begins 3-4 days after injection (see Fig. 4) and reaches a maximum after 810 days, when all animals were killed. Controls received a corresponding injection of sterile saline.

\section{Measurement of neuraminidase activity}

Neuraminidase activity was measured by a modification of the method of Potier et al. (1979), with 4MU-AcNeu as a fluorogenic substrate. Duplicate reactions contained $50 \mu \mathrm{l}$ of substrate $(200 \mu \mathrm{g} / \mathrm{ml}$ of buffer $), 50 \mu \mathrm{l}$ of

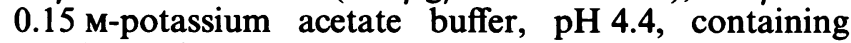
$0.05 \%$ Triton X-100, and exactly $200 \mu \mathrm{g}$ (cortex, medulla, papilla and liver) or $250 \mu \mathrm{g}$ (glomeruli) of protein in the same buffer in a final volume of $200 \mu \mathrm{l}$. Tubes were capped and incubated at $37^{\circ} \mathrm{C}$ for $1 \mathrm{~h}$. The reaction was terminated by immersing the tubes in ice/water, followed by immediate addition of $1.3 \mathrm{ml}$ of glycine/carbonate stopper $(0.133 \mathrm{M}$-glycine buffer, pH 10.7, containing $0.06 \mathrm{M}-\mathrm{NaCl}$ and $0.083 \mathrm{M}-\mathrm{Na}_{2} \mathrm{CO}_{3}$ ). Tubes were mixed well, allowed to reach room temperature, and the fluorescence was measured (excitation $365 \mathrm{~nm}$, emission $450 \mathrm{~nm}$ ). A separate enzyme blank (tissue added after stopper) was run for each sample. Neuraminidase activity was calculated as the mean of duplicate experimental tubes minus the enzyme blank and expressed as $\mathrm{nmol} / \mathrm{h}$ per $\mathrm{mg}$ of protein, calculated from a 4-methylumbelliferone standard curve run simultaneously with the samples. Under these conditions, neuraminidase activity was a linear function of tissue protein concentration (results not shown).

\section{Other methods}

$\alpha$-L-Fucosidase (EC 3.2.1.51) was assayed by the method of Barrett \& Heath (1977) as described in detail in our previous study (Baricos \& Shah, 1984). Tissue protein content was determined after solubilization in $0.1 \mathrm{M}-\mathrm{NaOH}$ by the method of Lowry et al. (1951), with bovine serum albumin (Sigma, type V) as the reference standard. Urinary protein content was measured by the Bio-Rad method as described by the manufacturer. DNA was measured as described by Fiszer-Szafarz $e t$ al. (1981), with calf thymus DNA as the standard. Colloidal-iron staining of glomerular AcNeu was carried 
out by the method of Mowry (1963) as described by Michael et al. (1970). Leucocytes were isolated by the dextran sedimentation method as described previously (Ritchey et al., 1981).

\section{RESULTS AND DISCUSSION}

\section{Biochemical characterization of glomerular neuraminidase}

The use of 4MU-AcNeu for the measurement of neuraminidase activity in renal tissues such as glomeruli or tubules has not previously been reported. Thus we first defined optimal assay conditions and examined some biochemical properties of glomerular neuraminidase, using 4MU-AcNeu. Because previous studies in our laboratory (W. H. Baricos, S. Cortez-Schwartz \& S. V. Shah, unpublished work) and by others (Tulsiani \& Carubelli, 1970; Myers et al., 1980; Alhadeff \& Wolfe, 1981; Den Tandt \& Scharpe, 1984; Spaltro \& Alhadeff, 1984; Cohen-Forterre et al., 1984; Miyagi \& Tsuiki, 1984) have shown significant losses of neuraminidase activity with freeze-thawing and on overnight storage, neuraminidase measurements in the various tisssue fractions were always carried out with fresh tissue on the day of killing.

In initial experiments we determined that neuraminidase activity in glomeruli, tubules and cortex was maximal at $\mathrm{pH}$ approx. 4.4 (Fig. 1), similar to the $\mathrm{pH}$ optimum

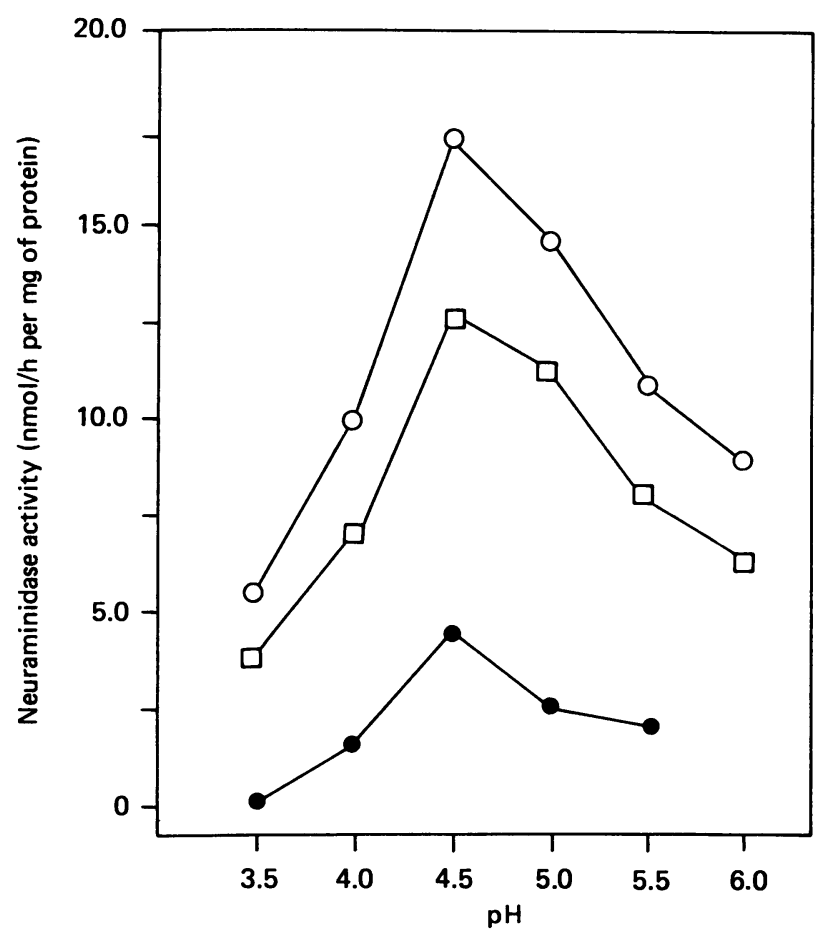

Fig. 1. Effect of pH on the rate of $4 \mathrm{MU}-\mathrm{AcNeu}$ hydrolysis by glomeruli (O), tubules ( $\square$ ) or cortex (O)

Homogenates of glomeruli, tubules and cortex (250 $\mu \mathrm{g}$, $200 \mu \mathrm{g}$ and $200 \mu \mathrm{g}$ of protein respectively) prepared from the same rats were incubated in $0.15 \mathrm{M}$-acetate buffer with $0.05 \%$ Triton $\mathrm{X}-100$ at each $\mathrm{pH}$ indicated for $60 \mathrm{~min}$ at $37^{\circ} \mathrm{C}$. Results are expressed as means of duplicate reactions corrected for the appropriate enzyme blank for each pH. Additional details are given in the Experimental section. reported for neuraminidase from whole kidney (Mahadevan et al., 1967; Kirschbaum \& Bosmann, 1973; Mutton et al., 1978). With glomeruli as the enzyme source, the Michaelis constant $\left(K_{\mathrm{m}}\right)$ for $4 \mathrm{MU}$-AcNeu was estimated to be $195 \mu \mathrm{M}$ (Fig. 2). In comparison, the $K_{\mathrm{m}}$ values for cortex and liver were estimated to be $226 \mu \mathrm{M}$ and $281 \mu \mathrm{M}$ respectively. Similar $K_{\mathrm{m}}$ values for this substrate have been reported with other tissues (Potier et al., 1979; Myers et al., 1980; Alhadeff \& Wolfe, 1981; Den Tandt \& Scharpe, 1984; Spaltro \& Alhadeff, 1984). Neuraminidase activity in glomeruli and liver was unaffected by $\mathrm{CaCl}_{2}$, EDTA and $N$-ethylmaleimide, each $1 \mathrm{~mm}$ (Table 1). The failure of $\mathrm{CaCl}_{2}$ to stimulate glomerular neuraminidase is in agreement with results obtained with other mammalian sources of this enzyme which, in contrast with bacterial neuraminidases, are not usually stimulated by $\mathrm{Ca}^{2+}$ (Rosenberg \& Schengrund, 1976). In keeping with previously published data for

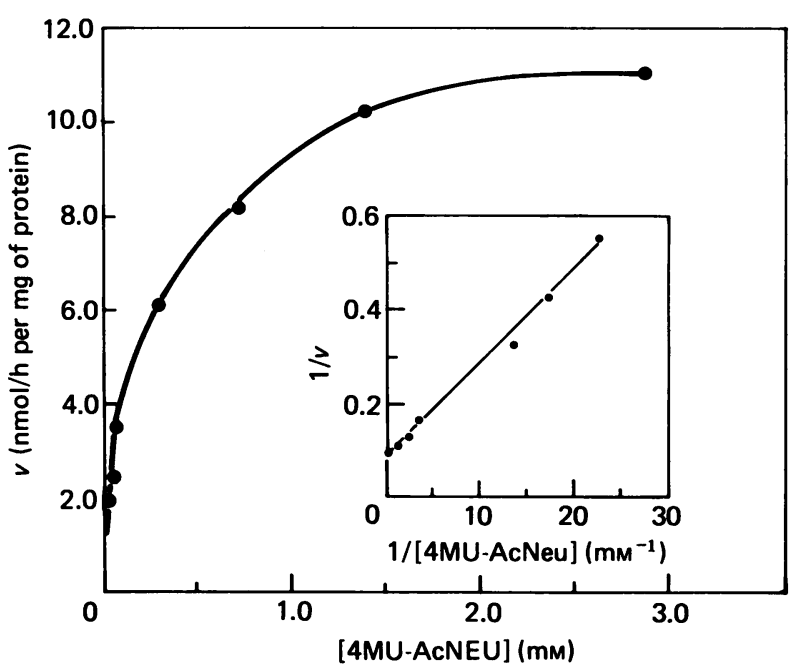

Fig. 2. Michaelis-Menten and double-reciprocal plot (Lineweaver-Burk) showing the effect of $4 \mathrm{MU}-\mathrm{AcNeu}$ concentration on its rate of hydrolysis by glomerular homogenate (250 $\mu \mathrm{g}$ of protein)

Each point represents the mean of triplicate determinations corrected for the appropriate enzyme blank. $K_{\mathrm{m}}$ was determined by linear regression analysis for $4 \mathrm{MU}-\mathrm{AcNeu}$ concentrations in the range $0.03-3.0 \mathrm{~mm}$. See the Experimental section for further details.

Table 1. Effect of various agents on neuraminidase activity in glomeruli and liver isolated from control rats

Results are means \pm S.E.M. for six separate determinations carried out in triplicate and corrected for the appropriate enzyme blank. See the Experimental section for further details.

\begin{tabular}{|c|c|c|}
\hline \multirow[b]{2}{*}{ Agent } & \multicolumn{2}{|c|}{ Neuraminidase $(\%$ of control $)$} \\
\hline & Glomeruli & Liver \\
\hline $\begin{array}{l}\mathrm{CaCl}_{2}(1 \mathrm{~mm}) \\
\text { EDTA (1 mM) } \\
N \text {-Ethylmaleimide (1 mM) } \\
\mathrm{HgCl}_{2}(1 \mathrm{mM}) \\
\text { Triton X-100 }(0.5 \%) \\
\text { AcNeu }(25 \mathrm{mM})\end{array}$ & $\begin{array}{r}99 \pm 1.0 \\
96 \pm 1.0 \\
103 \pm 1.0 \\
74 \pm 3.0 \\
75 \pm 3.0 \\
11 \pm 0.1\end{array}$ & $\begin{array}{r}108 \pm 2.0 \\
100 \pm 1.0 \\
92 \pm 1.0 \\
100 \pm 3.0 \\
82 \pm 3.0 \\
38 \pm 1.0\end{array}$ \\
\hline
\end{tabular}


neuraminidase from rat kidney (Mahadevan et al., 1967; Tuppy \& Palese, 1968; Cohen-Forterre et al., 1984), the failure of either EDTA or $N$-ethylmaleimide to affect glomerular neuraminidase activity suggests that neither metals nor free thiol groups are required for activity of the glomerular enzyme. As previously reported for whole kidney and other tissues, a slight inhibition of neuraminidase activity in glomeruli was observed with $\mathrm{HgCl}_{2}$ $(1 \mathrm{mM})$ and in both glomeruli and liver with relatively high concentrations $(0.5 \%)$ of Triton X-100 (Rosenberg \& Schengrund, 1976; Mahadevan et al., 1967). In contrast, low concentrations of this detergent usually increase neuraminidase activity, presumably by disruption of lysosomes (Horvat \& Touster, 1968; Tulsiani \& Carubelli, 1971). AcNeu (25 mM), a product of the reaction, caused a marked inhibition of neuraminidase activity in both glomeruli and liver (Table 1). Similar results have been reported by Potier et al. (1979), who showed that $25 \mathrm{~mm}$-AcNeu produced 'almost $100 \%$ inhibition' of leucocyte and fibroblast neuraminidase activity with $4 \mathrm{MU}-\mathrm{AcNeu}$ as substrate. The inhibition was of the competitive type, with a $K_{\mathrm{i}}$ of approx. $6.0 \mathrm{mM}$ for the enzyme from Vibrio cholerae.

\section{Neuraminidase activity in normal rat tissues}

Since the activity and distribution of neuraminidase in kidney tissue has not previously been reported, we first measured neuraminidase activity in the major anatomical subdivisions of the kidney: cortex, medulla, papilla and, for comparison, liver isolated from the same animals. As shown in Table 2, cortical neuraminidase activity was approximately twice that of medulla and nearly 6 times that of papilla and liver.

Leucocytes are rich sources of neuraminidase activity (Table 2). Although renal neuraminidase measurements were carried out on only well-blanched kidneys (see the Experimental section), the potential contribution of leucocyte neuraminidase to that measured in the kidney was investigated. Leucocytes from normal rats were isolated by the dextran sedimentation method as described previously (Ritchey et al., 1981), and neuraminidase activity was measured as described in the

\section{Table 2. Neuraminidase activity in control rat tissues}

Results are means \pm S.E.M. for the numbers of samples (carried out in duplicate and corrected for the appropriate enzyme blank) shown in parentheses. See the Experimental section for further details.

\begin{tabular}{lr}
\hline Tissue & $\begin{array}{c}\text { Neuraminidase } \\
\text { (nmol/h per mg } \\
\text { of protein) }\end{array}$ \\
\hline Cortex & $14.47 \pm 0.76(12)$ \\
Medulla & $7.85 \pm 0.64(12)$ \\
Papilla & $2.64 \pm 0.11(12)$ \\
Liver & $2.58 \pm 0.14(12)$ \\
Leucocytes & $0.19 \pm 0.01 *(9)$ \\
Cortex $\dagger$ & $13.40 \pm 0.92(28)$ \\
Tubules & $13.79 \pm 0.70(28)$ \\
Glomeruli & $5.57 \pm 0.28(28)$
\end{tabular}

* $\mathrm{nmol} / \mathrm{h}$ per $10^{6}$ cells.

+ Separate experimental group from the 12 above.
Experimental section. A separate group of anaesthetized rats were injected (intravenously) with ${ }^{125} \mathrm{I}-\mathrm{IgG}$. After 5-10 min, a sample of blood was obtained and the kidneys were perfused as described in the Experimental section. Simultaneous measurement of radioactivity in the kidneys and in a specific volume of blood allowed an estimate of residual renal blood to be calculated. This value $(92 \pm 9 \mu \mathrm{l} /$ kidney), combined with the leucocyte neuraminidase activity (Table 2 ) and the blood leucocyte count $(8370 \pm 463$, mean \pm S.E.M. $)$, demonstrated that leucocytes contributed less than $1 \%$ of the neuraminidase activity measured in the cortex.

Using a separate group of rats, we then measured neuraminidase activity in glomeruli and tubules isolated from the same cortex. Cortical neuraminidase activity was similar in this group to that described above. Neuraminidase activity in the tubule fraction was nearly identical with that of cortex, as expected from the composition of the cortex (approx. 90-95\% tubules) (Table 2). The lower activity in glomeruli compared with cortex and tubules is consistent with previously published data from our laboratory (Baricos \& Shah, 1984) and others (Velosa et al., 1981; Taylor et al., 1971; Lovett et al., 1982) for lysosomal enzymes, which, except for acid phosphatase, appear to have lower activity in glomeruli than in cortex or tubules. It is noteworthy, however, that the specific activity of neuraminidase in glomeruli is more than twice that of liver, usually considered the 'yardstick' organ for lysosomal enzymes.

\section{Glomerular neuraminidase activity in PAN-induced nephrotic syndrome}

Cohen-Forterre et al. (1984) have reported an increase in the specific activity of renal neuraminidase in rats with experimentally induced diabetes, a condition characterized by decreased glomerular AcNeu. To determine if a similar increase in neuraminidase activity might account for the loss of glomerular AcNeu observed in many types of glomerular disease (Michael et al., 1970; Chiu \& Drummond, 1972; Blau \& Haas, 1973; Bertani et al., 1982; Kerjaschki et al., 1985), we examined glomerular neuraminidase activity in PAN-induced nephrotic syndrome. The selection of this experimental model was based on the well-documented loss of AcNeu from GPA (Michael et al., 1970; Kerjaschki et al., 1985; Charest \& Roth, 1985) and the report of normal or possibly increased GPA biosynthesis (Blau \& Michael, 1972) in PAN-induced nephrotic syndrome.

As described in our previous study (Baricos \& Shah, 1984), PAN-treated rats developed proteinuria beginning on day 4 and reached a maximum value (mean) over $900 \mathrm{mg} / 24 \mathrm{~h}$ by day 9 , when all animals were killed (Fig. 3 ). This proteinuria was accompanied by hypoproteinaemia, ascites, lipaemia and significant loss of glomerular AcNeu as measured by colloidal-iron staining (Mowry, 1963; Michael et al., 1970) in all treated animals (results not shown).

In the first group, glomeruli and cortex were simultaneously isolated from PAN-treated and control rats killed at the time of heavy proteinuria (day 9). As shown in Table 3 , there was no significant change in neuraminidase activity in either glomeruli or cortex. In contrast, the activity of a second lysosomal enzyme, $\alpha$-L-fucosidase, was significantly decreased in the identical samples used for neuraminidase assay (Table 3).

To confirm these results and to investigate the 


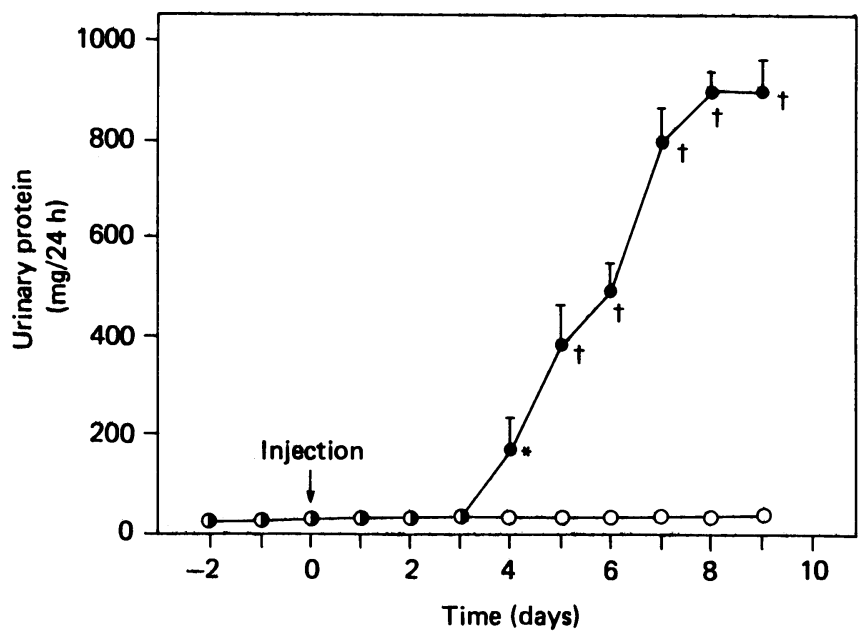

Fig. 3. Urinary protein excretion ( $\mathrm{mg} / 24 \mathrm{~h}$ ) in control (salineinjected; $O)$ and PAN-treated (15 mg/100 g body wt.; O) rats

Urinary protein was determined by the Bio-Rad protein assay. Values are expressed as means \pm S.E.M. for duplicate determinations for eight separate animals in each group. Significance of difference from controls: $* P<0.01$; $\dagger P<0.001$ (unpaired $t$ test). See the Experimental section for further details.

possibility that a transient change in neuraminidase activity may have occurred coincident with the onset of proteinuria, we carried out a second study in which we measured neuraminidase activity in PAN-treated rats killed at the onset (day 4: $174 \pm 61 \mathrm{mg} / 24 \mathrm{~h}$ ) as well as the peak (day 9: $901 \pm 63 \mathrm{mg} / 24 \mathrm{~h}$ ) of proteinuria. As shown in Fig. 4, neuraminidase activity in both 4- and 9-day controls was similar to the corresponding controls in the previous group (Table 3 ). In agreement with the previous experiment, we again observed no significant difference in the specific activity of neuraminidase in glomeruli or cortex isolated from PAN-treated rats killed at the time of heavy proteinuria (day 9). Furthermore, there was no change in neuraminidase activity in glomeruli or cortex isolated from rats killed at the onset of proteinuria (day 4, Fig. 4). These results were similar whether neuraminidase activity was expressed per $\mathrm{mg}$ of protein or per $\mu \mathrm{g}$ of DNA (results not shown).

In summary, our data indicate that $4 \mathrm{MU}-\mathrm{AcNeu}$ is a suitable substrate for the measurement of neuraminidase activity in glomeruli, tubules and kidney cortex, with as little as $50-100 \mu \mathrm{g}$ of tissue protein. Furthermore, our data demonstrate that normal glomeruli contain relatively

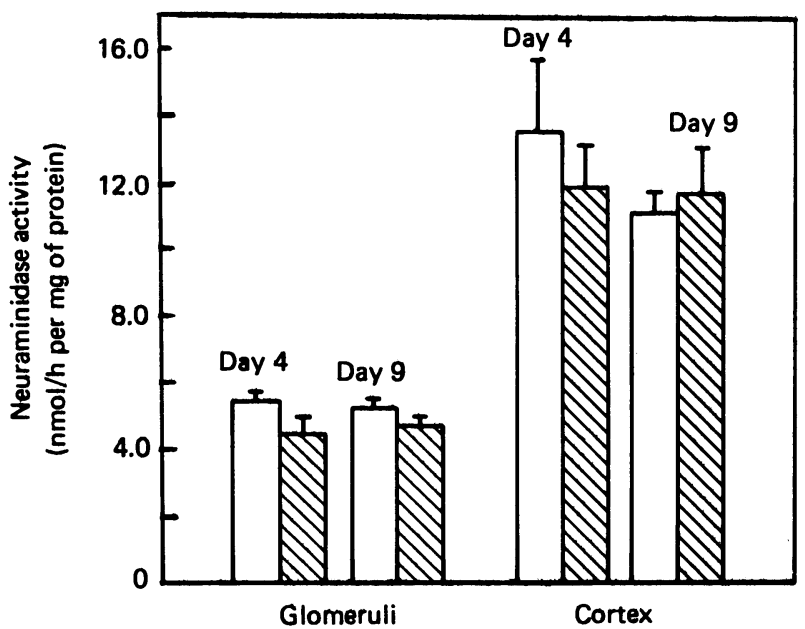

Fig. 4. Neuraminidase activity in glomeruli and cortex isolated from PAN-treated $(15 \mathrm{mg} / 100 \mathrm{~g}$ body wt.; $\mathbb{N})$ and control (saline-injected; $\square$ ) rats killed 4 days or 9 days after injection

Injections were staggered in order to allow the killing, tissue processing and simultaneous neuraminidase assay in glomeruli and cortex obtained from one animal in each control (4- and 9-day) and experimental (4- and 9-day) group. Results are expressed as means \pm S.E.M. for duplicate determinations, corrected for the appropriate enzyme blank, for ten animals in each group. See the Experimental section for further details.

high activity of neuraminidase, with properties similar to those previously described for neuraminidase in whole kidney and other tissues. Finally, in contrast with what might be expected (see the Introduction), changes in the activity of total glomerular neuraminidase do not occur in conjunction with either the onset or the frank expression of proteinuria associated with PAN-induced nephrotic syndrome.

Portions of this work have appeared in abstract form and were presented at the first meeting of the American Society of Renal Biochemistry and Metabolism, 17-19 May 1985, Cancun, Mexico). This work was supported in part by grants from the American Heart Association (81-1179), N.I.H. (2 ROl AM28452-04), the Medical Research Service, Veterans Administration Hospital, New Orleans, LA, and the Louisiana Affiliate of the American Heart Association. W.H.B. and S.V.S. are Established Investigators of the American Heart Association, with funds contributed in part by the Louisiana Affiliate of the American Heart Association. We acknowledge the technical assistance of S. Dipp and H. Nguyen.

Table 3. Comparison of neuraminidase and $a-\mathrm{L}-$ fucosidase activity in glomeruli, cortex and liver obtained from PAN-treated and control rats killed 9 days after injection

Results are means \pm S.E.M. ( $\mathrm{nmol} / \mathrm{h}$ per $\mathrm{mg}$ of protein) for duplicate determinations corrected for the appropriate enzyme blank for eight separate rats in each group. *Significantly different from controls $(P<0.01)$. See the Experimental section for details.

\begin{tabular}{|c|c|c|c|c|}
\hline \multirow[b]{2}{*}{ Tissue } & \multicolumn{2}{|c|}{ Neuraminidase } & \multicolumn{2}{|c|}{$\alpha$-L-Fucosidase } \\
\hline & Control & PAN-treated & Control & PAN-treated \\
\hline $\begin{array}{l}\text { Glomeruli } \\
\text { Cortex }\end{array}$ & $\begin{array}{r}6.26 \pm 0.62 \\
16.04 \pm 1.45\end{array}$ & $\begin{array}{r}5.91 \pm 0.47 \\
14.66 \pm 1.29\end{array}$ & $\begin{array}{r}73.9 \pm 7.1 \\
234.3 \pm 28.3\end{array}$ & $\begin{array}{r}45.1 \pm 6.2^{*} \\
125.5 \pm 18.6^{*}\end{array}$ \\
\hline
\end{tabular}




\section{REFERENCES}

Abboud, H. E., Ou, S.-L., Velosa, J. A., Shah, S. V. \& Dousa, T. P. (1982) J. Clin. Invest. 69, 327-336

Alhadeff, J. A. \& Wolfe, S. (1981) Int. J. Biochem. 13, 975980

Andrews, P. M. (1979) Kidney Int. 15, 376-385

Baricos, W. H. \& Shah, S. V. (1984) Biochem. J. 223, 393-399

Barrett, A. J. \& Heath, M. F. (1977) in Lysosomes, a Laboratory Handbook (Dingle, J. T., ed.), pp. 118-120, Elsevier/North-Holland, Amsterdam

Bertani, T., Poggi, A., Pozzoni, R., Delaini, F., Sacchi, G., Thoua, Y., Mecca, G., Remuzzi, G. \& Donati, M. B. (1982) Lab. Invest. 46, 16-23

Blau, E. B. \& Haas, J. E. (1973) Lab. Invest. 28, 477-481

Blau, E. B. \& Michael, A. F. (1972) Proc. Soc. Exp. Biol. Med. 141, 164-172

Carubelli, R., Trucco, R. E. \& Caputto, R. (1962) Biochim. Biophys. Acta 60, 196-197

Charest, P. M. \& Roth, J. (1985) Proc. Natl. Acad. Sci. U.S.A. 82, 8508-8512

Chiu, J. \& Drummond, K. N. (1972) Am. J. Pathol. 28, 391400

Cohen-Forterre, L., Mozere, G., Andre, J. \& Sternberg, M. (1984) Biochim Biophys. Acta 801, 138-145

Couser, W. G., Jermanovich, N. B., Belok, S. \& Stilmant, M. M. (1978) J. Clin. Invest. 61, 561-572

Den Tandt, W. R. \& Scharpe, S. (1984) Biochem. Med. 31, 287-293

Fiszer-Szafarz, B., Szafarz, D. \& deMurillo, A. G. (1981) Anal. Biochem. 110, 165-170

Frenk, S., Antonowicz, I., Craig, J. M. \& Metcoff, J. (1955) Proc. Soc. Exp. Biol. Med. 89, 424-427

Horvat, A. \& Touster, O. (1968) J. Biol. Chem. 243, 43804390

Kanwar, Y. S. \& Farquhar, M. G. (1980) Lab. Invest. 42, 375-384

Kerjaschki, D., Sharkey, D. J. \& Farquhar, M. G. (1984) J. Cell Biol. 98, 1591-1596

Kerjaschki, D., Vernillo, A. T. \& Farquhar, M. G. (1985) Am. J. Pathol. 118, 343-349

Kirschbaum, B. B. \& Bosmann, H. B. (1973) Nephron 11, 2639

Received 11 March 1986/16 June 1986; accepted 11 July 1986
Kuratowska, Z. \& Kubicka, T. (1967) Acta Biochim. Pol. 14, 255-259

Lovett, D. H., Ryan, J. L., Kashgarian, M. \& Sterzel, R. B. (1982) Am. J. Pathol. 107, 161-166

Lowry, O. H., Rosebrough, N. J., Farr, A. L. \& Randall, R. J. (1951) J. Biol. Chem. 193, 265-275

Mahadevan, S., Nduaguba, J. C. \& Tappel, A. L. (1967) J. Biol. Chem. 242, 4409-4413

Meyer, D. M., Lemonnier, M. \& Bourrillon, R. (1981) Biochem. Biophys. Res. Commun. 103, 1302-1309

Michael, A. F., Blau, E. \& Vernier, R. L. (1970) Lab. Invest. 23, 649-657

Miyagi, T. \& Tsuiki, S. (1984) Eur. J. Biochem. 141, 75-81

Mohos, S. C. \& Skoza, L. (1969) Science 164, 1519-1521

Mowry, R. W. (1963) Ann. N.Y. Acad. Sci. 106, 402-423

Mutton, T., Resnick, M. \& Boyce, W. H. (1978) Invest. Urol. 15, 419-421

Myers, R. W., Lee, R. T., Lee, Y. C., Thomas, G. H., Reynolds, L. W. \& Uchida, Y. (1980) Anal. Biochem. 101, 166-174

Potier, M., Mameli, L., Belisle, M., Dallaire, L. \& Melancon, S. B. (1979) Anal. Biochem. 94, 287-296

Ritchey, E. E., Wallin, J. D. \& Shah, S. V. (1981) Kidney Int. 19, 349-358

Rosenberg, A. \& Schengrund, C.-L. (1976) in Biological Roles of Sialic Acid (Rosenberg, A. \& Schengrund, C.-L., eds.), pp. 295-359, Plenum Press, New York

Spaltro, J. \& Alhadeff, J. A. (1984) Biochim. Biophys. Acta 800, 159-165

Suzuki, K. (1976) in Biological Roles of Sialic Acid (Rosenberg, A. \& Schengrund, C.-L., eds.), pp. 159-181, Plenum Press, New York

Taylor, G. D., Price, R. G. \& Robinson, D. (1971) Biochem. J. 122, 641-645

Tulsiani, D. R. P. \& Carubelli, R. (1970) J. Biol. Chem. 245, $1821-1827$

Tulsiani, D. R. P. \& Carubelli, R. (1971) Biochim. Biophys. Acta, 227, 139-153

Tuppy, V. H. \& Palese, P. (1968) Hoppe-Seyler's Z. Physiol. Chem. 349S, 1169-1178

Velosa, J. A., Shah, S. V., Ou, S.-L., Abboud, H. E. \& Dousa, T. P. (1981) Lab. Invest. 45, 522-526 